\title{
PENINGKATAN POWER TUNGKAI PESILAT REMAJA MELALUI LATIHAN PLIOMETRIK
}

\author{
Siswantoyo \\ Fakultas Ilmu Keolahragaan Universitas Negeri Yogyakarta \\ email: splc_fikuny@yahoo.com
}

\begin{abstract}
Abstrak: Penelitian ini bertujuan untuk mengungkap pola perubahan power tungkai melalui latihan pliometrik yang dimodifikasi. Rancangan penelitian berupa eksperimen semu dengan times series. Pengukuran dilakukan sebanyak empat kali secara periodik. Populasi penelitian ini adalah pesilat remaja yang berjumlah 35 orang, sedang sampel berjumlah 15 orang yang diambil secara purposive. Pengukuran power tungkai menggunakan alat power jump DF Digital dengan satuan $\mathrm{cm}$. Data dianalisis dengan statistik deskriptif. Hasil penelitian menunjukan bahwa rerata pada tes ke-1: 40,6 $\mathrm{cm}$, tes ke-2: 43,4 cm, test ke-3: 45,2 cm dan tes ke-4: 47,2 cm. Kondisi tersebut menunjukkan bahwa latihan pliometrik yang dimodifikasi dapat meningkatkan power tungkai secara kontinyu dan cenderung terjadi peningkatan. Selain itu, juga diperoleh perubahan power tungkai pada setiap dua minggu pengukuran dengan pola pada rerata meningkat-menurun dan meningkat kembali. Kesimpulan adalah model latihan pliometrik dapat digunakan sebagai alternatif latihan untuk meningkatkan power tungkai pesilat remaja.
\end{abstract}

Kata Kunci: pliometrik, power tungkai, pesilat remaja

\section{THE IMPROVEMENT OF THE LEG POWER OF TEENAGER FIGHTERS THROUGH PLYOMETRIC TRAINING}

\begin{abstract}
This study aimed to investigate the pattern of changes in the leg power through modified plyometric training. This study was a time series quasi experiment. The measurements were done four times periodically. The population were 35 teenager fighters. The sample consisting of 15 males was taken by using the purposive sampling technique. The leg power was measured using a Digital DF power jump leg measurement with $\mathrm{cm}$ units. The data were analyzed descriptively. The findings showed that the average on $1^{\text {st }}$ test: $40.6 \mathrm{~cm}$, that on the $2^{\text {nd }}$ test: $43.4 \mathrm{~cm}$, that on the $3^{\text {rd }}$ test: $45.2 \mathrm{~cm}$ and that on the $4^{\text {rh }}$ test: $47.2 \mathrm{~cm}$. Based on the findings, it could be concluded that the modified plyometrictraining could improve the leg power and that there was a tendency of improvement. Besides, it was also revealed that the change of the leg power in every other week tended to increase, decrease, and increase again. Therefore, it could be concluded that the modified plyometric training model could be used as an alternative training to improve the leg power of teenager fighters.
\end{abstract}

Keywords: Plyometric, leg power, teenager fighter

\section{PENDAHULUAN}

Untuk mencapai prestasi maksimal dalam cabang pencak silat, diperlukan sebuah pembinaan yang panjang. Peran seorang pelatih, pelatih fisik, atlet, ahli gizi, dan beberapa ahli lain juga sangat penting dalam proses pembinaan untuk mencapai prestasi tersebut. Pembinaan jangka panjang diawali dari tahap multilateral dengan pengenalan berbagai cabang olahraga, tahap pembentukan sampai tahap spesialisasi salah satu cabang tertentu yang benar-benar digeluti dan prospektif terhadap pencapaian prestasi maksimal (Bompa, 1994:5). Peran dan tugas pelatih sangat besar dalam proses pencapaian prestasi, antara lain mempersiapkan kemampuan fisik, teknik, taktik, dan mental atlet. Untuk mencapai prestasi perlu ditingkatkan unsur-unsur kemampuan fisik, seperti: kekuatan (strength), daya tahan (endurance), daya ledak otot (muscular power), kecepatan (speed), kelentukan (flexibility), koordinasi (coordination), kelincahan (agility), ketepatan (accuracy), waktu reaksi (reaction time) dan lainnya. 
Plyometric training is popular among individuals involved in dynamic sports, and plyometric exercises such as jumping, hopping, skipping and bounding are executed with a goal to increase dynamic muscular performance (Impellizzeri dkk, 2008). Plyometric training has been applied in numerous studies, and there is a general consensus that it improves sport specific skills such as agility (Miller dkk, 2006) and vertical jump performance, common measures of muscle power (Markovic, 2007).

Latihan pliometrik telah digunakan sebagai metode latihan terutama untuk mengembangkan kekuatan, kecepatan, dan power (Redcliffe dan Farentinos, 1985:2). Pliometrik berasal dari akar kata Yunani, plio berarti lebih dan metric berarti pengukuran. Dengan metode ini, latihan ditekankan pada suatu bentuk latihan yang mempunyai ciri kontraksi otot dengan kekuatan penuh sebagai respon terhadap pembebanan yang cepat dan dinamis (Chu, 1992:520), dengan proses sistem kerja dari sistem neuromuskular antara lain terkait dengan reflek regang, muscle spindle dan golgi tendon organ (Costil, 1994). Kekuatan kecepatan dan power adalah serangkaian komponen fisik yang sangat penting dalam berbagai cabang olahraga. Dalamcabang pencak silat, power otot tungkai memiliki persentase lebih besar bila dibandingkan dengan unsur keseimbangan dan kelincahan. Salah satu bentuk latihan untuk meningkatkan power tungkai dapat dilakukan dengan latihan pliometrik. Prinsip latihan pliometrik dapat digunakan pada berbagai olahraga yang lain (Radcliffe dan Farentinos, 1985:9).

Strength training has become an essential method for optimizing athletic performance, especially in sports where explosive strength and speed are key determinants (Baker and Newton, 2008). Numerous authors have studied the strength changes produced in different athletic activities (e.g. jumps, sprints, or maximum repetitions) as a result of power-centered training (Cormie, 2010).

Oleh karena itu, dengan latihan pliometrik seseorang dapat meningkatkan kekuatan, kecepatan, dan power melalui proses peregang- an dan pemendekan serabut otot. Latihan pliometrik dengan latihan lompat dapat meningkatkan hasil lompatan lebih baik dan mampu membuat otot-otot pada extremitas bawah lebih kuat dan mengurangi resiko cedera. Berdasarkan hasil observasi diperoleh bahwa power tungkai pesilat remaja masih relatif kurang. Hal ini dapat dilihat secara empirik bahwa tendangan yang dilakukan di beberapa kompetisi remaja masih sangat lemah. Hal ini menunjukkan bahwa power tungkai masih rendah.

Latihan pliometrik modifikasi adalah bentuk latihan kombinasi dari latihan yang dilakukan dengan lompat berselang-seling. Latihan yang digunakan dalam penelitian ini adalah side double front jump modification, yaitu melompat kearah depan-samping dan lompat kedepan dengan melewati rintangan. Dalam penelitian ini akan membuktikan modifikasi latihan pliometrik untuk meningkatkan power tungkai pada pesilat remaja.

Berdasarkanuraian di atas, dapat dirumuskan permasalahan penelitian sebagai berikut. Bagaimanakah pola perubahan power tungkai pesilat remaja melalui latihan pliometrik? Penelitian ini bertujuan untuk mengetahui hasil latihan pliometrik terhadap pola perubahan power tungkai. Hasil yang diperoleh diharapkan dapat memberi informasi bagi perkembangan iptek, khususnya ilmu keolahragaan, dan sumbangan pengetahuan bagi atlet, pelatih, dan pembina olahraga dalam memilih model latihan untuk meningkatkan power tungkai.

\section{METODE}

Penelitian ini merupakan penelitian eksperimental semu dengan menggunakan rancangan times series design (Zainuddin, 2000). Rancangan dalam penelitian ini dapat digambarkan seperti berikut.

$$
\begin{gathered}
\text { perlakuan/treatment } \\
\text { Sampel }(\mathrm{S}) \rightarrow \mathrm{T} 1 \rightarrow \mathrm{T} 2 \rightarrow \mathrm{T} 3 \rightarrow \mathrm{T} 4
\end{gathered}
$$

Keterangan:

T1-T4: pengukuran secara berkala setiap terjadi peningkatan beban/2minggu.

Populasi pada penelitian ini adalah pesilat remaja sejumlah 35 orang. Sample dipilih dengan teknik purposive sampling. Sample di- 
tetapkan dengan kriteria jenis kelamin laki-laki, tingkat pemula, sanggup aktif latihan, dan tidak hadir maksimal empat kali. Berdasarkan kriteria tersebut, diperoleh sampel sejumlah 15 orang pesilat.

Pada penelitian ini variabel yang diukur adalah power tungkai. Alat untuk mengukur power tungkai dengan menggunakan Jump DF Digital Test dengan satuan $\mathrm{cm}$. Program latihan dilakukan selama 6 minggu, 3 kali/minggu, peningkatan beban dilakukan secara periodik setiap 2 minggu. Pengumpulan data dilakukan dengan teknik tes dan pengukuran sebanyak 4 kali, dilakukan secara periodik setiap 2 minggu. Data dianalisis secara deskriptif inferensial, dengan mencari nilai rata-rata dan standart deviasi untuk melihat adanya pola perubahan peningkatan power tungkai pada pesilat.

\section{HASIL DAN PEMBAHASAN \\ Hasil}

Secara deskriptif, data penelitian hasil pengukuran power tungkai dapat dilihat pada Tabel 1. Peningkatan power tungkai pada pesilat remaja dari 4 kali pengukuran dapat dilihat pada Gambar 1.
Peningkatan power tungkai dari tes 1 sampai tes 4 secara umum terjadi indikasi peningkatan yang progresif. Namun, apabila dilihat dari selisih peningkatan rata-rata masing-masing tes nampak adanya sebuah fluktuasi, yang akan dikupas lebih detail pada pembahasan.

\section{Pembahasan}

Pencak silat merupakan salah satu jenis olahraga beladiri yang berakar dari rumpun Melayu. Pada prinsipnya, pencak silat memiliki empat aspek, yaitu aspek mental spiritual, seni, beladiri, dan olahraga. Aspek olahraga telah dikembangkan model kompetisi dengan kategori tanding dan seni: tunggal, ganda dan regu dan dikelompokan berdasarkan tingkat usia, yaitu kelompok usia dini, pra remaja, remaja, dewasa. Pada kategori tanding diperlukan unsur fisik, teknik, taktik, dan kematangan mental. Berdasarkan karakteristiknya, pertandingan pencak silat dilakukan untuk meraih angka tertinggi dalam setiap babak. Untuk menjadi pemenang, pesilat harus memiliki kemampuan fisik yang baik, teknik dan taktik yang handal, kecerdasan, dan kematangan mental.

Tabel 1. Data Peningkatan Power Tungkai Pesilat Remaja melalui Latihan Pliometrik (cm)

\begin{tabular}{cccccccc}
\hline Data tes & N & Min & Max & $\begin{array}{c}\text { Rerata } \\
(\mathrm{cm})\end{array}$ & $\begin{array}{c}\text { Std. } \\
\text { Deviasi }\end{array}$ & Normalitas & Homogenitas \\
\hline Tes 1 & 15 & 28.00 & 55.00 & 40.60 & 7.00 & 0.45 & 0.70 \\
Tes 2 & 15 & 31.00 & 56.00 & 43.40 & 6.45 & & \\
Tes 3 & 15 & 35.00 & 57.00 & 45.20 & 5.54 & $(\mathrm{p}>0.05)$ & $(\mathrm{p}>0.05)$ \\
Tes 4 & 15 & 38.00 & 59.00 & 47.20 & 5.47 & normal & homogen \\
\hline
\end{tabular}

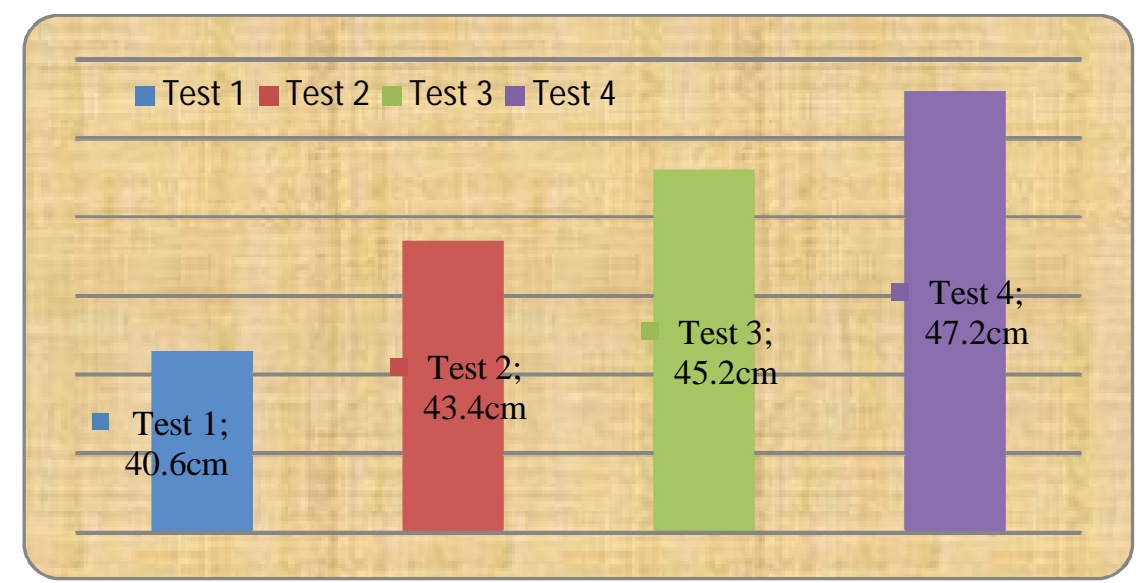

Gambar 1: Peningkatan Power Tungkai Pesilat Remaja 
Unsur fisik yang dominan dalam pencak silat antara lain power, daya tahan aerobik, dan anaerobik, kecepatan reaksi, kelincahan, kelentukan, kekuatan, dan lainnya. Untuk menjadi pesilat yang mumpuni, unsur fisik perlu ditingkatkan secara maksimal.

Unsur fisik yang diperlukan untuk melakukan tendangan adalah power tungkai. Power tungkai akan terbentuk apabila pesilat telah memiliki atau dilatih unsur fisik yang mendasri $p o$ wer, yaitu kekuatan dan kecepatan. Dosis latihan untuk meningkatkan kekuatan dan kecepatan bervariasi. Villarreal dkk, (2010) mengatakan bahwa, "Training volume of less than 10 weeks and with more than 15 sessions, as well as the inclusion of high-intensity programs, with more than 40 jumps per session, were the strategies that seem to maximize the probability to obtain significantly greater improvements in leg muscle strength". Jadi, untuk meningkatkan kekuatan otot tungkai diperlukan dosis pembebanan yang sesuai. Sejalan dengan hal tersebut, Perez-Gomez dkk, (2008) mengatakan bahwa latihan selama 6 minggu dapat menggunakan model latihan pliometrik dan latihan beban. Selanjutnya, ditegaskan oleh Fernandez, dkk. (2013) bahwa latihan kekuatan dengan beban power maksimum akan lebih efektif dalam peningkatan kekuatan dan akselerasi.

Power diperoleh dari kombinasi antara unsur kekuatan dan kecepatan. Menurut Vaczi dkk (2013), latihan pliometrik memungkinkan untuk dikombinasikan dengan kecepatan sprint dan kekuatan. Selain itu, Malisoux, dkk. (2006) menjelaskan bahwa latihan unilateral secara ekstensif dapat digunakan pada atlet dengan berbagai variasi umur dan tingkatan untuk memaksimalkan kecepatan sprint, tinggi, dan jarak lompatan. Selain itu, juga dapat digunakan untuk latihan rekreasional.

Dalam kajian ini diungkap peningkatan power tungkai melalui latihan pliometrik dengan program latihan yang telah dipersiapkan. Perlakuan dalam penelitian ini dilaksanakan dengan program latihan selama 6 minggu, 3 kali/ minggu, dan dilakukan pada sore hari. Dosis latihan yang diberikan akan merangsang tubuh untuk beradaptasi secara fisiologis. Tabel 1 me- nunjukkan hasil rerata setiap tes yang dilakukan secara periodik. Grafik 1 menunjukkan hasil pengukuran power tungkai, dimana hasil tersebut terdapat indikasi adanya peningkatan. Hal ini disebabkan karena rangsang latihan pliometrik dengan lompat memberikan pengaruh yang berbeda-beda pada setiap pesilat. Adanya pengaruh peningkatan power tungkai disebabkan oleh banyak faktor, antara lain respons otot yang terlibat, kemampuan adaptasi fisiologis pesilat, dan lainnya. Adaptasi terhadap stimulus berupa latihan pliometrik tersebut menyebabkan munculnya sebuah pola perubahan peningkatan power tungkai dari waktu ke waktu. Secara rinci, faktor-faktor yang mempengaruhi power tungkai diuraikan sebagai berikut.

\section{Otot yang Terlibat dalam Aktivitas}

Tabel 1 menunjukkan peningkatan power tungkai yang berbeda-beda dari tes pertama, kedua, ketiga, dan ke empat. Peningkatan ini tidak terlepas dari respons adaptasi otot yang terlibat untuk mengatasi beban yang diberikan berupa program yang terstruktur, teratur, dan terukur. Program latihan dilakukan dalam waktu yang relatif lama sehingga program latihan ini bila dilihat dari definisi konsep latihan termasuk pada definisi training. Aktivitas latihan (training) kata Kent (1994:456) memiliki makna suatu program yang dirancang untuk membantu pembelajaran keterampilan, memperbaiki kesegaran jasmani untuk menyiapkan atlet menghadapi kompetisi tertentu. Pada setiap kali latihan selalu tersusun terstruktur dengan latihan peregangan (stretching), latihan pemanasan (warming $u p$ ), dilanjutkan dengan latihan inti. Kemudian, dilanjutkan dengan latihan penenangan (cooling down), dan diakhiri dengan latihan peregangan (Fox, dkk., 1993:288). Aktivitas tersebut selalu melibatkan otot-otot besar dan kecil pada tubuh. Program yang dilakukan telah memenuhi unsurunsur yang terdapat dalam konsep training.

Pada latihan pliometrik, otot yang banyak terlibat adalah otot-otot pada ektremitas bawah. Pada tungkai secara fisiologis terdapat berbagai macam otot, baik yang termasuk otot besar maupun otot kecil. Otot rangka dalam tubuh manusia terdiri lebih kurang 40-50\% dari keseluruh- 
an massa tubuh, sedangkan 5-10\% yang lainnya merupakan otot polos dan otot jantung (Tortora, 1994). Tungkai terdiri dari tungkai bawah dan tungkai atas. Pada tungkai atas, terdapat $m и s c u$ lus quadriceps femoris, rectus femoris, vastus alteralis, hamstring, musculus sartorius, maductor longus, gracilis, dan lainnya, sedangkan pada tungkai bawah terdapat musculus gastrocnemius, soleus, peroneus longus, extensor digitorum, dan lainnya.

Bentuk perlakuan pliometrik yang dimodifikasi dilakukan dengan kombinasi arah gerakan yang bervariasi ke arah samping, depan, belakang. Dengan arah yang lebih bervariasi sangat dimungkinkan adanya keterlibatan otot yang lebih banyak, baik otot kecil maupun otot besar, khususnya pada tungkai. Perbedaan keterlibatan otot dalam aktivitas ini sangat berpengaruh terhadap hasil lompatan atau power tungkai. Sebagai contoh perbedaan yang sangat nyata adalah yang terjadi pada landasan stabil dan labil. Pada landasan labil, otot memang benar-benar melakukan kerja yang cukup berat dan adaptasi yang ditimbulkan juga jauh lebih baik dari latihan pada landasan stabil. Sebab pada landasan stabil, otot yang digunakan untuk beraktivitas tidak mengalami adanya stress akibat beban yang diberikan, sehingga adaptasi yang terjadi kurang maksimal. Hal tersebut dapat terjadi karena beban yang diterima merupakan beban normal tanpa adanya kelabilan landasan yang juga menambah beban tersendiri.

Jika dibandingkan dengan latihan beban (weight training), latihan pliometrik memberikan keuntungan ganda (Chu,1992:1-3). Pliometrik memanfaatkan gaya dan kecepatan yang dicapai dengan percepatan berat badan melawan gravitasi. Hal ini menyebabkan gaya dan kecepatan latihan beban tersedia. Latihan pliometrik lebih sering digunakan pada berbagai aktivitas olahraga, seperti melompat, berlari dan melempar dibanding dengan latihan beban. Vaczi dkk, (2013) menegaskan bahwa latihan pliometrik dapat dikombinasikan dengan sprint dan strength.

\section{Usia Perkembangan dan Adaptasi}

Kematangan fisik pesilat untuk mencapai prestasi puncak sejalan dengan konsep tumbuh kembang anak. Teori golden age atau usia emas di berbagai cabang olahraga biasanya berada pada rentang usia 14-25 tahun. Catatan sejarah usia perkembangan dan prestasi dapat dilihat pada atlet-atlet dunia, seperti stefi Graff yang muncul sebagai Juara Wimbledon pada usia 17 tahun, Andrea Reducan dari Rumania menjadi bintang Olimpiade Sidney 2000 pada usia 16 tahun. Hal tersebut menunjukkan adanya pola pembinaan yang terstruktur dan terukur dengan program yang tepat dan pembinaan jangka panjang yang sesuai. Untuk mencapai prestasi perlu dilakukan pembinaan jangka panjang dan dibutuhkan waktu lebih kurang 6-10 tahun. Dalam penelitian ini, sampel yang digunakan berada pada rentang usia remaja. Menurut PB IPSI (2007), pencak silat kategori tanding dikelompokkan berdasarkan usia, yaitu usia dini (10-12 tahun), pra remaja (di atas 12-14 tahun), remaja (di atas 14-17 tahun), dan dewasa (di atas 17-35 tahun).

Pesilat yang digunakan dalam penelitian ini berusia remaja dengan rentang usia 14-15 tahun. Pesilat remaja telah diberikan bentuk-bentuk latihan yang mendasari untuk peningkatan power dengan latihan berupa kekuatan, kecepatan, daya tahan, dan lainnya. Latihan yang diberikan untuk meningkatkan power tungkai pesilat remaja dengan bentuk latihan pliometrik dimana beban yang diberikan berasal dari beban dalam dengan berat badan sendiri. Dengan demikian, diharapkan terjadi adaptasi fisiologis yang normal sesuai dengan kemampuan normal. Adaptasi otot saat melakukan latihan pliometrik dapat dijelaskan dengan dasar fisiologis kerja otot.

Proses sistem kerja pada latihan pliometrik tidak lepas dari sistem neuromuskular, yakni gerakan yang terletak pada jalur reflek. Reflek regang pada serabut otot yang sama disebut "stretch reflex". Otot memiliki reseptor sensorik yang peka bila serabut otot teregang berupa kumparan otot atau "muscle spindle" dan reseptor yang peka bila otot mengalami proses pemendekan. Selain itu, juga bila tendon yang teregang, yaitu berupa "golgi tendon organ" melalui proprioseptor tersebut pengaturan siklus regang dan pemendekan otot dapat dikontrol. 
Akan tetapi, pada latihan pliometrik kumparan otot merupakan hal yang lebih penting dari gerakan reflek tersebut (Radcliffe dan Farentinos, 1985:7). Namun demikian, beban yang diberikan dengan menggunakan berat badan sendiri.

Yusuf (2002:156) mengatakan bahwa sejalan dengan pertumbuhan fisik anak yang semakin tinggi dan besar, maka semakin meningkat pula kemampuan dan keterampilan fisiknya seperti kekuatan, kelentukan, keseimbangan, power, koordinasi dan lainnya. Berawal dari hal tersebut, maka pada tahap usia tersebut perlu diberikan beban dosis latihan yang sesuai dengan tumbuh kembangnya.

Melalui pemberian beban dosis latihan yang terukur, akan terjadi adaptasi fisiologis yang baik. Hasil penelitian menunjukkan adanya peningkatan power tungkai dari tes pertama hingga tes keempat sebesar $6.6 \mathrm{~cm}$. Adaptasi berupa peningkatan power tungkai yang diperoleh tersebut dipengaruhi oleh berbagai faktor, antara lain kualitas otot, pemberian beban yang tepat, dan motivasi pesilat untuk menjalankan program. Adaptasi fisiologis terjadi karena rangsang beban yang diterima oleh otot dapat direspons tubuh dengan mekanisme coping yang baik. Mekanisme coping merupakan respons tubuh melalui psikofisiologis bahwa beban yang dilakukan mampu diadaptasi dengan situasi kondisi psikologis yang menyenangkan, sehingga saat melakukan program dengan penuh keyakinan dan kegembiraan. Di samping itu, juga telah terjadi adaptasi eustress, yaitu tubuh secara molekuler mampu mengatasi beban yang diberikan sehingga menimbulkan dampak yang positif. Dengan demikian, terjadi peningkatan kemampuan. Namun, apabila tubuh tidak mampu mengatasi beban tersebut, akan terjadi dampak negatif berupa penurunan dan cenderung terjadi disease.

Salah satu teori adaptasi yang dikemukakan oleh Selye biasa disebut dengan GAS (General Adaptation Sindrome). GAS menurut Selye terjadi saat organisme mengalami stress yang panjang atau lama dan organ tubuh yang lain juga ikut dipengaruhi oleh kondisi stres tersebut. General adaptation Sindrome ini terbagi atas tiga tahap sebagai berikut.
- Alarm Reaction Stage (reaksi peringatan): merupakan reaksi awal tubuh dalam menghadapi berbagai stresor. Tubuh tidak dapat mempertahankan tahap ini dalam waktu yang lama.

- Resistance/Adaptation Stage: Tubuh mulai beradaptasi dengan adanya stres dan berusaha mengatasi stresor. Kemampuan tubuh dalam mengatasi stresor akan berdampak positif pada tubuh yang dicerminkan dengan berbagai peningkatan ke arah perbaikan. Sebaliknya, apabila tubuh tidak mampu dalam mengatasi beban yang ada, maka akan berakibat ke arah lebih rentan terhadap penyakit atau akan terjadi penurunan.

- Exhaustion Stage (tahap kelelahan): merupakan tahap ketika adaptasi tidak dapat dipertahankan, disebabkan karena stres yang berulang atau berkepanjangan sehingga stres berdampak pada seluruh tubuh. General adaptation sindrome yang diungkapkan oleh Hans Selye tersebut di atas sesuai dengan yang digambarkan oleh Rushall (1990) sebagaimana terlihat pada Gambar 2.

Adaptasi yang terjadi dalam penelitian ini dijelaskan pada Gambar 2, yaitu tentang pola perubahan peningkatan power tungkai pesilat remaja. Perubahan yang terjadi identik dengan teori adaptasi yang dikemukakan oleh Selye dan digambarkan oleh Rushal (1990). Adaptasi yang lain juga dilaporkan oleh Makaruk dkk. (2011), yaitu pada wanita tidak terlatih yang melakukan latihan dengan unilateral jump meningkatkan power dan tinggi lompatan dalam waktu yang relatif pendek dibandingkan dengan latihan bilateral jump. Dalam masa partumbuhan untuk mencapai tinggi lompatan yang maksimal diperlukan adaptasi terhadap pemberian beban latihan. Dalam kajian ini, perubahan beban latihan dilakukan setiap dua minggu.

Prinsip peningkatan beban latihan dalam penelitian ini sesuai dengan prinsip overloading yang dikemukakan Bompa (1999). Beban latihan harus mencapai ambang rangsang. Bila dalam latihan tubuh sudah beradaptasi dengan beban yang diberikan, maka beban latihan berikutnya harus ditingkatkan dengan cara diperberat, dipercepat, dan diperlama. Overloading prin- 
ciple dalam Bompa (1999) dapat dilihat pada Gambar 3.

Adaptasi beban latihan dengan tujuan untuk meningkatkan kemampuan fisik dan mengurangi cedera pesilat remaja. Pada beban awal latihan pliometrik semua pesilat remaja diberi beban rintangan setinggi $40 \mathrm{~cm}$ dan selanjutnya berangsur terjadi peningkatan rintangan yang semakin lama semakin tinggi selama 6 minggu. Power, kekuatan, kelincahan merupakan faktor yang penting dalam olahraga yang memerlukan gerak dinamis seperti melompat, berlari sprint, berhenti, merubah arah, dan gerak lain yang dilakukan (Vaczi dkk, 2013).

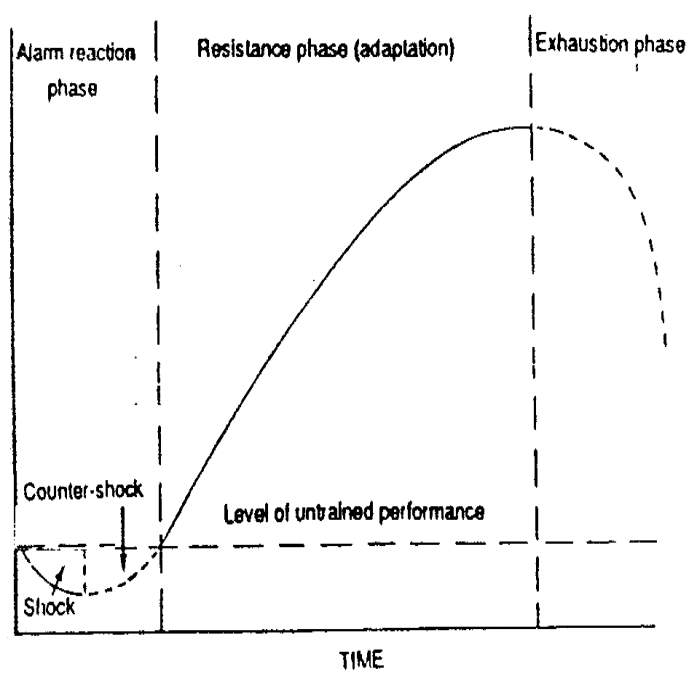

\section{Gambar 2. Pola Respons Adaptasi Tubuh pada Pemberian Dosis Latihan Fisik}

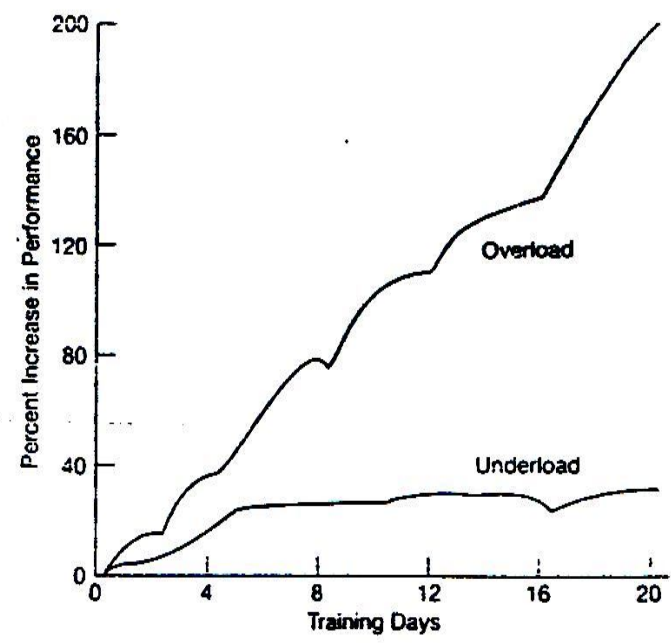

Gambar 3. Overloading Principle
Untuk melakukan model dan bentuk latihan pliometrik seperti dalam kajian ini, diperlukan motivasi yang cukup tinggi dari para pesilat remaja. Berdasarkan hasil observasi, para pesilat remaja dalam menjalankan program latihan menunjukkan semangat dan motivasi yang sangat tinggi. Proses latihan dengan beban yang terukur memberikan dampak psikologis pada pesilat. Peningkatan kecerdasan emosional merupakan hasil psikologis yang diinginkan dari proses yang dilakukan (Rustiana, 2013). Hal ini dimungkinkan para pesilat remaja secara personal masing-masing telah mempunyai tujuan untuk dapat meningkatkan power tungkai dan akan menyebabkan tendangan semakin baik dengan harapan dapat digunakan dalam rangka meraih prestasi pada saat kompetisi.

\section{Program Latihan dan Pola Perubahan Pe- ningkatan Power Tungkai}

Program latihan akan berdampak baik apabila dosis yang diberikan sesuai dan memberikan rangsang yang tepat terhadap tubuh. Dalam penyusunan programtidak terlepas dari dosis latihan. Beban latihan dapat dikatakan sebagai dosis latihan fisik. Yang dimaksud dosis latihan antara lain seperti berikut. (1) Intensitas latihan, dapat diartikan sebagai kualitas beban (ringan, sedang, berat atau low moderate, sub maximal, maximal, super maximal). (2) Frekuensi latihan merupakan jumlah kejadian/ulangan. (3) Durasi latihan, diartikan sebagai lamanya latihan dilaksanakan. Durasi latihan juga akan mempengaruhi perubahan adaptasi tubuh. (4) Jenis latihan atau bentuk latihan, yaitu karakteristik latihan dari intensitas, frekuensi dan durasi latihan (Fox, 1993).

Dalam penelitian ini, pelaksanaan perlakuan selama 6 minggu, frekuensi $3 \mathrm{kali} / \mathrm{ming}$ gu, intensitas sub maksimal-maksimal, dan bentuk latihan dengan pliometrik. Pliometrik adalah sebuah metode untuk mengembangkan explosive power yang penting dalam komponen penampilan olahraga (Radcliffe dan Farentinos, 1985:1).

Bentuk-bentuk latihan pliometrik menurut Radcliffe dan Farentinos (1985:30-108) antara lain: double leg bound, alternate leg bound, 
double leg box bound, alternate leg box bound, incline bound, lateral bound, double leg speed hop, single leg speed hop, incremental vertical hop, decline hop, side hop, angle hop, squat jump, knee tuck jump, split jump, scissor jump, box jump, depth jump, single leg stride jump, stride jump crossover, side jump/sprint, quick leap, depth jump lead, skipping, box skip, incline ricochet, decline ricochet, floor kip, horizontal swing, vertical swing, medicine ball twist/toss, bar twist, medicine ball sit up throw, medicine ball leg toss, medicine ball scoop toss, medicine ball chest pass, heavy bag thrust, dumbbell arm swing, heavy bag stroke, medicine ball throw. Bentuk-bentuk latihan ini pada prinsipnya dapat dikelompokkan menjadi bentuk latihan untuk melatih otot tubuh bagian bawah, tengah, dan atas.

Dalam penelitian ini, bentuk latihan yang diberikan adalah side double front jump modification, yaitu melompat ke arah depan-samping dan lompat ke depan dengan melewati rintangan. Hasil penelitian yang dilakukan Vaczi dkk,
(2013) dengan latihan pliometrik selama 6 minggu diperoleh power tungkai dengan tes vertical jump, pada kelompok perlakuan pretest $44.8 \mathrm{~cm}$ dan postest $48.8 \mathrm{~cm}$, sedangkan kelompok kontrol pretest $40.62 \mathrm{~cm}$ dan postest $40.55 \mathrm{~cm}$. Hasil tersebut sangat jelas bahwa latihan pliometrik pada kelompok perlakuan terjadi peningkatan sebesar $4 \mathrm{~cm}$ sedangkan kelompok kontrol terjadi penurunan sebesar $0.07 \mathrm{~cm}$. Hasil penelitian Vaczi, dkk (2013) sejalan dengan temuan dalam penelitian ini. Secara keseluruhan dari empat kali pengukuran terjadi peningkatan yang progresif. Hasil tes pertama sampai keempat terjadi peningkatan yang bervariatif. Bila dilihat selisih peningkatan secara bertahap sesuai dengan tahapan tes, dapat dibuat sebuah pola atau trend peningkatan power tungkai pesilat remaja dengan latihan pliometrik. Pola perubahan peningkatan power tungkai tersebut dapat di tampilkan dalam gambar. Hasil peningkatan power tungkai dapat dibuat pola perubahan seperti Gambar 4.

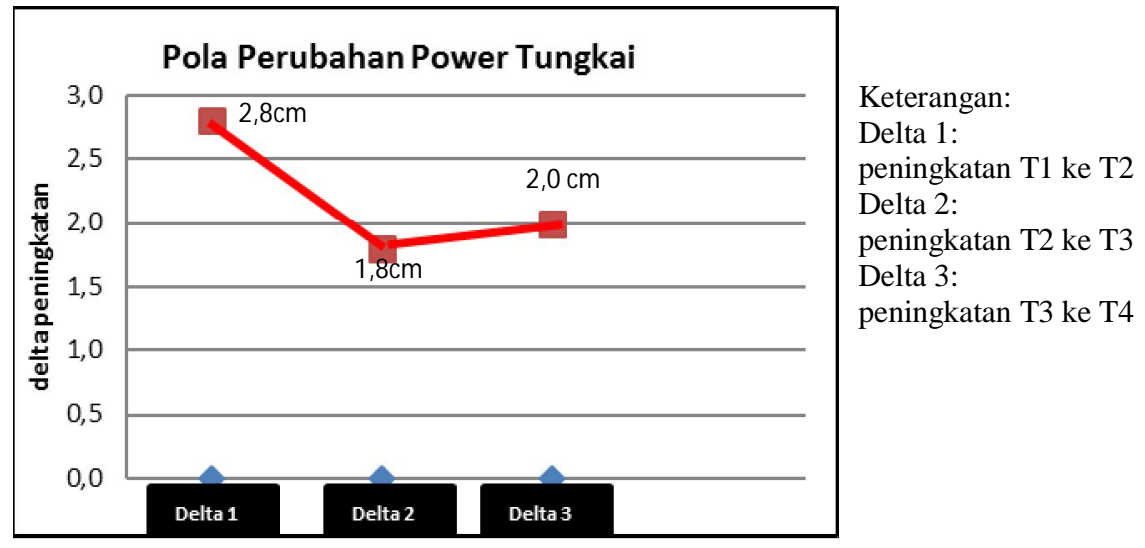

Gambar 4: Pola Perubahan Power Tungkai dengan Latihan Pliometrik

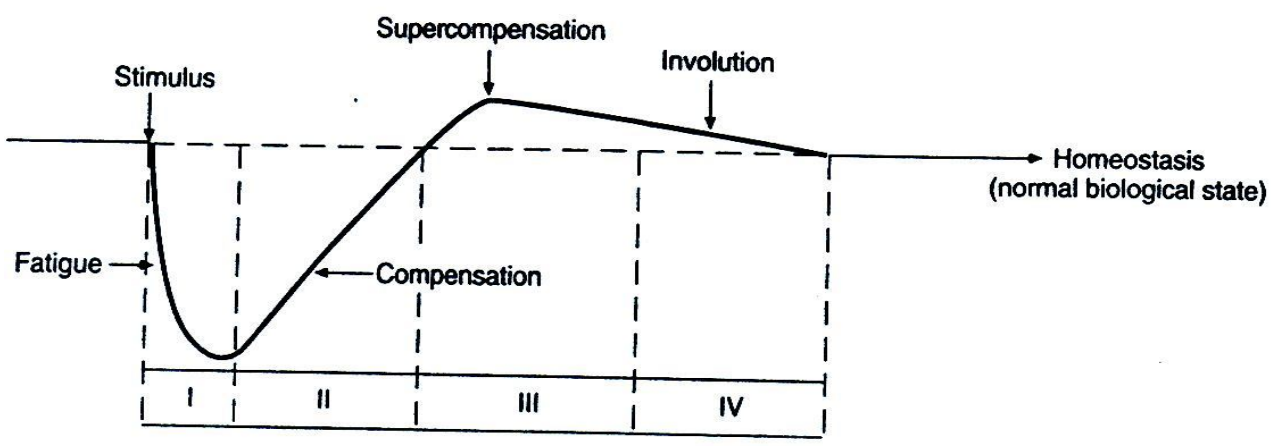

Gambar 5: Teori Adaptasi 
Gambar 4 di atas menunjukkan bahwa pola perubahan peningkatan power tungkai dari tes 1 ke tes 2 dengan selisih hasil peningkatan rerata $2.8 \mathrm{~cm}$ (delta 1 ), sedangkan pada tes 2 ke tes 3 dengan selisih hasil rerata $1.8 \mathrm{~cm}$ (delta 2). Hal tersebut berarti terjadi penurunan rerata jika dibandingkan dengan delta 1 , dan pada tes 3 ke tes 4 dengan selisih hasil peningkatan rerata 2,0 $\mathrm{cm}$ (delta 3), jika dibandingkan dengan delta 2 menunjukkan adanya sedikit peningkatan rerata $0.2 \mathrm{~cm}$. Pola perubahan peningkatan power tungkai ini dapat dijelaskan secara fisiologi exercise bahwa pada awal latihan otot belum mengalami kelelahan dalam waktu yang panjang. Pesilat secara psikologis masih memiliki motivasi yang sangat tinggi sehingga mereka dapat melakukan perlakuan dan test secara maksimal pula. Pada delta 2 terjadi penurunan karena otot telah mengalami kelelahan yang berarti, dan memerlukan fase untuk pemulihan dan adaptasi dari beban latihan yang diberikan. Namun demikian, pada delta 3 menunjukkan adanya kecenderungan peningkatan power tungkai. Berdasarkan teori adaptasi dapat dijelaskan sebagai berikut.

Latihan dengan jumlah frekuensi pada setiap minggu berbeda. Hal tersebut tentu akan menghasilkan adaptasi yang berbeda pula. Frekuensi latihan 2 kali, 4 kali, dan 5 kali /minggu akan memberikan respons adaptasi tubuh yang berbeda-beda (Fox, 1993). Latihan dengan pemberian beban yang terukur dan program latihan yang teratur, serta terarah akan menimbulkan adaptasi dalam tubuh seperti yang digambarkan oleh Bompa (1999) sebagaimana terlihat pada Gambar 5.

Latihan fisik dengan penetapan dosis yang sangat berlebihan akan menimbulkan dampak yang kurang baik terhadap tubuh. Latihan fisik menyebabkan perubahan besar dalam sistem sirkulasi dan pernafasan, namun keduanya berlangsung bersamaan dan terpadu sebagai bagian dari respons homeostasis (Ganong, 1998).

Dalam penelitianini, pada fase superkompensasi belum menunjukkan peningkatan yang lebih tinggi. Hal ini dimungkinkan karena program latihan hanya dilakukan selama 6 minggu saja, dan dimungkinkan fase superkompensasi akan terjadi pada saat program tersebut dilakukan pada minggu-minggu berikutnya. Vaczi, dkk. (2013:23) mengatakan bahwa hal tersebut juga dimungkinkan untuk mengoptimalkan volume, frekuensi latihan, dan durasi yang berbeda untuk meningkatkan performance seperti kemampuan melompat, waktu sprint, kelincahan dan kekuatan.

Vaczi, dkk. (2013) juga melaporkan bahwa dengan latihan pliometrik juga berpengaruh terhadap perubahan kemampuan fisik yang lain seperti kelincahan pada kelompok perlakuan terjadi peningkatan sebesar 0.26 detik (15.3415.08 detik), sedangkan kontrol sebesar 0.21 detik (15.83-15.62 detik). Kecepatan sprint pada kelompok perlakuan terjadi peningkatan sebesar 0.29 detik (11.72-11.43 detik) dan kelompok kontrol terjadi penurunan sebesar 0.11 detik (11.87-11.92 detik). Dengan demikian, hasil penelitian pliometrik pada pesilat remaja ini dapat melengkapi kajian tentang efek dari latihan pliometrik pada berbagai jenis olahraga yang telah dilakukan sebelumnya.

Thomas, dkk. (2009) juga menemukan bahwa latihan pliometrik selama 6 minggu secara signifikan meningkatkan kelincahan sebesar 9\% pada pemain sepakbola remaja, dan meningkat lebih besar lagi (10\%) pada kelompok anak-anak setelah latihan pliometrik selama 8 minggu (Meylan and Malatesta, 2009). Miller, dkk. (2006) juga mengatakan bahwa setelah latihan pliometrik selama 6 minggu ditemukan peningkatan 3\% pada unsur kelincahan. Adaptasi yang lain juga dilaporkan oleh Arazi and Asadi (2011) yang mengatakan bahwa terjdi peningkatan sebesar $15 \%$ terhadap kemampuan leg press pada atlet semi profesional basket putra setelah berlatih dengan pliometrik selama 8 minggu. Dengan melihat hasil kajian dari penelitian yang lain tersebut, dapat disimpulkan bahwa hasil penelitian pliometrik pada pesilat remaja yang dilakukan selama 6 minggu belum mencapai pada puncak adaptasi power tungkainya.

Hasil Penelitian Vaczi, dkk. (2013) dapat disimpulkan bahwa latihan pliometrik memiliki impact dari latihan unilateral dan bilateral yang 
tinggi untuk merangsang peningkatan power pada ekstremitas bawah dan kekuatan maksimal knee extesor. Pada penelitian pliometrik seperti ini, dapat dipengaruhi oleh beberapa faktor seperti jenis kelamin, status latihan, metode testing, perbedaan alat dan jenis perlengkapan, perbedaan durasi latihan, intensitas, dan jenis serta program latihannya (Markovic, 2007).

Makaruk, dkk. (2011) menegaskan bahwa latihan pliometrik yang hanya dilakukan 6 minggu akan meningkatkan kemampuan vertical jump dalam waktu yang pendek. Selanjutnya, disarankan untuk berubah menjadi power yang lebih baik, perlu dilakukan adaptasi sampai ke sistem saraf, "Specifically with an increased neural drive to the agonist muscles and changes in the muscle activation strategies (i.e. improved intermuscular coordination), or changes in the mechanical characteristics of the muscle-tendon complex (Markovic \& Mikulic, 2010). Sejalan dengan hasil penelitian dan kajian di atas, dapat disimpulkan bahwa adaptasi akan mencapai titik tertinggi dari sebuah perlakuan atau stimuli pada latihan yang dilakukan selama 8 minggu. Hal ini lebih dikuatkan oleh teori adaptasi dari hasil penelitian Markovic, (2010), Arazi \& Asadi (2011), dan Meylan \& Malatesta, (2009).

\section{PENUTUP}

Berdasarkan hasil dan pembahasan di atas, dapat disimpulkan bahwa terdapat peningkatan kemampuan power tungkai pesilat remaja sebesar $6,6 \mathrm{~cm}$. Perubahan peningkatan power tungkai terjadi dengan pola meningkat-menurun-meningkat kembali. Dengan demikian, latihan pliometrik yang dimodifikasi dapat menjadi salah satu alternatif latihan untuk meningkatkan power tungkai. Bentuk latihan pliometrik ini dapat digunakan sebagai acuan para pelatih olahraga dalam memberikan perlakuan terhadap atlet pada saat latihan untuk meningkatkan power tungkai pesilat remaja.

\section{UCAPAN TERIMA KASIH}

Terima kasih yang setinggi-tingginya diucapkan kepada Fakultas Ilmu Keolahragaan UNY, para pesilat remaja dan semua pihak yang telah membantu terlaksananya penelitian ini. Terima kasih juga diucapkan kepada Redaktur dan Staf Jurnal Cakrawala Pendidikan.

\section{DAFTAR PUSTAKA}

Arazi, H. \& Asadi, A. 2011. "The Effect of Aquatic and Land Plyometric Training on Strength, Sprint, and Balance in Young Basketball Players". J Hum Sport Exerc. 6, pp: 101-111

Baker, DG, Newton RU. 2008. "Comparison of Lower Body Strength, Power, Acceleration, Speed, Agility, and Sprint Momentum to Describe and Compare Playing Rank among Professional Rugby League Players". J Strength Cond Res. 22(1): 153-158.

Bompa. T. O. 1994. Theory and Methodology of Training. Dubuque: Kendal/Hunt Publishing Co.

Bompa. T.O, 1999. Periodization, Theory and Methodology of Training. $4^{\text {th }}$ ed. Dubuque: Kendal/Hunt Publishing.

Costill, DL, Wilmore JH. 1994, "Physiology of Sport and Exercise." USA: Human Kinetics. pp. 349, 376, 536.

Chu, DA, 1992. Jumping in to Plyometrics. Champaign. Illinois: Leisure Pres.

Cormie, P, McGuigan MR, Newton RU. 2010. "Adaptations in Athletic Performance after Ballistic Power versus Strength Training”. Med Sci Sports Exerc, 42(8), pp: 1582-1598.

Fernandez, C B, Gonzalez C M, Vecino J C, \& Curiel D A. 2013. "The Effect of Maximal Power Training Cycle on Strength, Maximum Power, Vertical Height and Acceleration of High-Level 400 M Hurdlers." Journal of Human Kinetics. Vol. 36, pp: 119-126. 
Fox, EL, Bower RW, \& Foss MC. 1993. The Physiological Basisfor Exercise \& Sport. Iowa: Brown \& Benchmark Publisher.

Ganong, F. W. 1998. Fisiologi Kedokteran. Jakarta: Penerbit Buku Kedokteran EGC.

Impellizzeri, FM, Rampinini E, Castagna C, Martino F, Fiorini S, Wisloff U. 2008. "Effects of Plyometric Training on Sand Versus Grass on Muscle Soreness and Jumping and Sprinting Ability in Soccer Players". Br J Sports Med. 42, pp: 42-46.

Kent, M. 1994. The Oxford Dictionary of Sports Science and Medicine. New York: Oxford University Press.

Markovic, G. 2007. "Does Plyometric Training Improve Vertical Jump Height? A MetaAnalytical Review". Br J Sports Med. 41, pp: 349-355.

Meylan C. \& Malatesta, D. 2009. "Effects of in-Season Plyometric Training within Soccer Practice on Explosive Actions of Young Players". J Strength Cond Res. 23, pp: 2605-2613.

Miller, MG, Herniman JJ, Richard MD, Cheatham CC, Michael TJ. 2006. "The Effects of a 6-Week Plyometric Training Program on Agility". J Sports Sci Med, 5, pp: 459-465.

Makaruk, H, Winchester JB, Sadowski J, Czaplicki A, \& Sacewicz T. 2011. "Effects of Unilateral and Bilateral Plyometric Training on Power and Jumping Ability in Women". J Strength Cond Res. 25, pp: 3311-3318

Malisoux, L, Francaux M, Nielens H, \& Theisen D. 2006. "Stretch-Shortening Cycle Exercises: anEffective Training Paradigm to Enhance Power Output of Human Single Muscle Fibers". J Appl Physiol, 100, pp: 771-779.
Markovic, G. \& Mikulic, P. 2010. "NeuroMusculoskeletal and Performance Adaptations to Lower-Extremity Plyometric Training”. Sports Med. 40, pp: 859-895.

PB IPSI. 2007. Pedoman Pertandingan Pencak Silat. Padepokan Pencak Silat TMII. Jakarta.

Perez-Gomez J, Olmedillas H, Delgado-Guerra S, Royo IA, Vicente-Rodriguez G, Ortiz RA, Chavarren J, Calbet JA. 2008. "Effects of Weight Lifting Training Combined with Plyometric Exercises on Physical Fitness,Body Composition, and Knee Extension Velocity during Kicking in Football”. Appl Physiol Nutr Metabol. 33, pp: 501-510.

Radcliffe, JC \& Farentinos, RC. 1985. Plyometrics Explosive Power Training. $2^{\text {nd }}$ ed. Champaign, Illionis: Human Kinetics $\mathrm{Pu}-$ blished, Inc.

Rushall, BS \& Pyke FS. 1990.Training of Sport and Fitness, $1^{\text {st }}$ ed. Melabourne: Macmillan co.

Rustiana, ER. 2013. "Upaya Peningkatan Kecerdasan Emosi Siswa Sekolah Dasar melalui Pendidikan Jasmani Harmoni”. Cakrawala Pendidikan. Tahun XXXII, No. 1. hlm. 139-149.

Thomas, K, French, D, \& Hayes, PR. 2009. "The Effects of Two Plyometric Training Techniques on Muscular Power and Agility in Youth Soccer Players". J Strength Cond Res, 23, pp: 332-335.

Tortora, GJ \& Grabowski, SR. 1994. Principles of Anatomy and Physiology. $7^{\text {th }}$ ed. New York: Harper Collins College Publishers.

Vaczi, M., Jozsef T, Mezler B, Juhazs I, \& Karsai I. 2013. "Short-Term High Intensity Plyometric Training Program Improves Strength, Power and Agility in Male 
Soccer Players". Journal of Human Kinetics. 36, p:17-26.

Villarreal, E S, Requena B, \& Newton RU. 2010. "Does Plyometric Training Improve Strength Performance? AMeta-Analysis". J Sci Med Sport.13, p: 513-522.
Yusuf, Muh. 2002. "Meningkatkan Prestasi Olahraga dengan Teori Perhitungan Golden Age". Jurnal Ilmiah SPIRIT. Vol. 2, No. 2 hal. 156.

Zainuddin, M. 2000. Metodologi Penelitian. Surabaya: Pascasarjana Universitas Airlangga. 